\title{
Organizational Charts in a Selection of LIBER Libraries : Analysis of Current Trends
}

\author{
by SUZANNE JOUGUELET
}

\section{INTRODUCTION}

The survey of organization structures analyzed in this paper was launched at the end of 2005 by the LIBER Division Library Management and Administration (LMA). It was conducted electronically in a representative group of LIBER libraries located across Europe: 78 libraries from 33 countries. It has been analyzed by the LMA Division's committee and a member of the staff of the Bibliothèque nationale de France $(\mathrm{BnF})$, allocating groups of countries between them, with the very important help of the French school of librarianship. I want to give warm thanks to all the colleagues who have responded and to those who have helped in the analysis of this very rich material.

The selection of libraries was made by the members of the committee, according to their geographical contacts. The answers give an uneven geographic representation (see Appendix 2) and the libraries are of different types and sizes, but all are research libraries affiliated to LIBER.

The main purpose of the survey was to gain an insight into what organization charts can tell us about the evolution of research libraries in different European countries. The key goals were to compare organization and service arrangements in a range of libraries, to gain an understanding of changes in recent years, as evidenced by the organization charts, and to analyse trends in the evolution of organizations, rather than arriving at firm quantifiable findings concerning change.

Our intention was not to investigate change in general, but merely to look at the way it has been expressed through organization charts (and their evolution over time). The work is indicative rather than scientifically significant.

\section{WHY HAVE ORGANIZATION CHARTS BEEN UPDATED AND HOW?}

The principal reason is reform in many libraries during the last 3 years or plans in the near future, allied to the modification of existing services and/or introduction of new ones:

- to simplify the organization, making it more efficient and flexible so that levels of responsibility are clearly identified: for example, reduction in the number of departmental libraries;

- to create - or improve - a standardized service policy;

- to incorporate new services, especially IT and digital services,

- $\quad$ or alternatively, budget cuts.

The update is also often linked to a merger with another department or library. Some examples will be analyzed below.

The major change that has been made is the merging of functional units, especially technical services. Let us look at some examples:

- $\quad$ merging serials, cataloguing, acquisitions and special collections into one department (Kosovo); merging the cataloguing and acquisitions departments into one department (Czech Republic, Switzerland, Turkey);

- merging reader service and reference work service;

- $\quad$ merging binding and stacks group (Switzerland);

- $\quad$ merging legal services and contracts services (France). 
New functional units may be created - the National Library of Scotland has created a 'Development Department' in 2005, primarily for fundraising activities. New IT and electronic departments, merging information systems and a digital library have been created in French academic libraries, in Belgium and in the Netherlands (Tilburg University Library), with the aid of an important reorganization. In some cases, there is an extension of scope - for example in the National Library of Lithuania, the Department of Rare Books, Collections and Archives has become responsible for digitization.

Cross-functional responsibilities on different subjects emerge - staff training, e-literacy courses, record management, services for the handicapped. An important trend is the restructuring of management teams, often to better define levels of management and responsibility, sometimes to produce a more centralized organization (between a main library and faculty libraries for example). To manage new activities, task groups are created for specific targets, e.g. digitization, e-content etc.

\section{CHANGES IN USER SERVICES}

It is in the area of user services that the creation of new services or significant changes is most obvious. We can distinguish between on-site and on-line services. On-site, new facilities and services are offered: a new reading room for non-book collections (Wales), a new visitor center (Scotland), and a new audiovisual section (Turkey). Opening hours are greatly extended (Manchester, UK). New programmes of cultural events are organized (Switzerland, Germany). Internet access is offered in library public areas using wifi technology (Croatia, Czech Republic, Lithuania, Slovakia). A vast range of changes in the information offered to users is introduced. The reading rooms become learning centers; the "ask a librarian" service is developed. On-line, there is a major development of e-resources: online access to all catalogues, linking technology for periodicals, institutional repositories and open access. Online access is constantly enriched with new digitized sections of the holdings of the libraries, portals, for various eresources of one library as well as for a network of libraries; virtual reference services are either in place or planned.

A new Department for the development of digital library services has been created in Groningen University Library; online services are grouped in a new entity in Lyon I University Library: SIBE (Système d'Information et Bibliothèque Électronique). The creation of institutional repositories is increasing.

To the question "Do new services mean the discontinuation of old services?" the answer is often that it is more a reorganization than a replacement of services. To the question "How are the readers persuaded to use online services?" some answer, "It is not necessary, they already know," but most of the respondents indicate all sorts of methods, such as communication, website alerts, mailings, newsletters, training, etc.

Different locations across Europe display different levels of e-service adoption. The question of budget is central, especially with the increasing price of e-resources and the need for digitization.

- The Netherlands and the Nordic countries are ahead in electronic services.

- In Eastern Europe, the most significant introduction of IT to basic library activities took place in the late 1990s and nowadays there is high adoption of 'new services' operated by library systems.

- $\quad$ Staff structure: the major trends revealed by the survey are specialization, coordination and integration.

Some interesting remarks have been formulated by the respondents:

- "Our staff structure is currently weighted towards traditional on site services. However we are in the process of significant service developments to widen access and develop new customer service standards. These developments will target resources, where they are most needed by customers" (National Library of Scotland).

- "More and more the difference is reflected in competence of the staff that we require in order to provide online services. Part of the staff needs re-training" (National Library of Croatia).

- "There is an important addition to the traditional tasks of acquisitions with the digitization programmes, the virtual reference service, the web legal deposit” (National Library of France).

- "The library IT group has been extended with information specialists who are working on online tutorials, E-only projects and implementation. Basically the first level help desk in the library is serving primarily the users who 
are coming to and working in the library. Information specialists are more focused on the services to teachers and researchers who hardly come to the physical library anymore"(Tilburg University Library, NL).

At the same time, more specialization is needed for, as the staff and libraries experience problems of funding, the staff should be used more efficiently.

\section{FINDINGS REGARDING WEB ACTIVITIES}

Usually there is a specific web group maintaining a web presence. Web activities can also be integrated in the IT department or be outsourced (in a few cases). Creating content is a broader activity, involving almost all departments (with subject specialists) or a group of people representing different library activities (for different parts of the web site).

In the Nordic countries, the normal situation is that the libraries have a limited web group dealing with internet activities. But almost all departments provide contributions to the content of the web services. Links with the parent institution (in the case of university libraries) are mostly direct links between library and university web sites or sometimes integration into the university website. Most university libraries follow university templates and house style.

\section{ADAPTATION TO DIGITAL ISSUES}

Analysis of the adaptation of the libraries organization to digital issues is very interesting. Many libraries respond 'new units' without giving their name. In some cases, specific units have been created, for example:

- Department for digital development and production (KB - Denmark)

- $\quad$ E-Library Development Office (N\&UL of Slovenia)

- Department of Restoration and Digitisation (NL of Latvia)

- Department of the creation of virtual library (NL of Lithuania)

Sometimes this is one person: Electronic resources manager (N\&UL of Iceland), Electronic resources librarian (Library Vrije Universiteit Brussels). There is also an e-resources librarian as part of the collection development subject specialist team in the University of London Research Library services. You can find a combination of a specific unit and a dedicated person in the National Library of Scotland (NLS): a Digital Library Division, based within the Strategy and Communication Department is responsible for the NLS website, digitization programmes and library systems. There is also an Electronic Collection Development Coordination based within the legal deposit unit, in the Collections Development Department.

Alternatively, the IT department has been developed: Directorate for informatics (National Széchényi Library, Hungary), IT Unit (Tilburg, NL). 


\section{National Librarian}

\begin{tabular}{|c|c|c|c|c|}
\hline $\begin{array}{l}\text { Collection } \\
\text { Development }\end{array}$ & $\begin{array}{l}\text { Corporate } \\
\text { Services }\end{array}$ & $\begin{array}{l}\text { Customer } \\
\text { Services }\end{array}$ & $\begin{array}{c}\text { Strategy and } \\
\text { Communications }\end{array}$ & Development \\
\hline $\begin{array}{l}\text { Manuscript } \\
\text { Collections }\end{array}$ & Estates & $\begin{array}{l}\text { Cataloguing } \\
\text { Services }\end{array}$ & Digital Libray & Development \\
\hline Map Collections & Finance & $\begin{array}{c}\text { Education \& } \\
\text { Imterpretative } \\
\text { Services }\end{array}$ & Marketing Services & \\
\hline $\begin{array}{c}\text { Legal Deposit \& } \\
\text { Modern } \\
\text { Collections }\end{array}$ & $\begin{array}{l}\text { Human } \\
\text { Resources }\end{array}$ & $\begin{array}{l}\text { Enquiries \& } \\
\text { Reference } \\
\text { Services }\end{array}$ & Strategic Policy & \\
\hline $\begin{array}{l}\text { Presenvation \& } \\
\text { Conservation }\end{array}$ & $\mathrm{NCT}$ & $\begin{array}{l}\text { Inter-Library } \\
\text { Services }\end{array}$ & & \\
\hline \multicolumn{5}{|l|}{$\begin{array}{l}\text { Rare Book } \\
\text { Collections }\end{array}$} \\
\hline $\begin{array}{l}\text { Business } \\
\text { Information }\end{array}$ & & & & \\
\hline
\end{tabular}

Organization chart National Library of Scotland

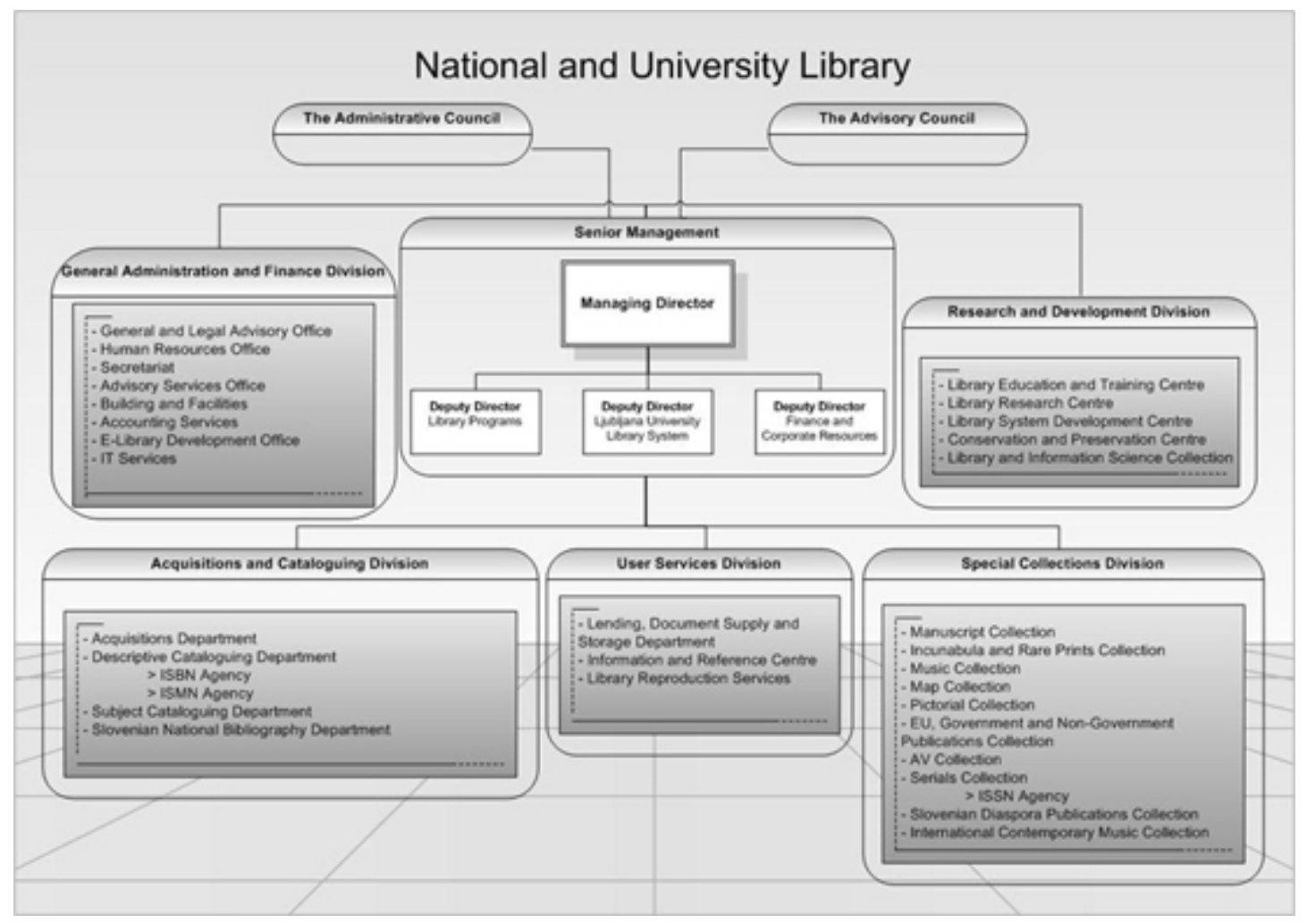

Organization chart National and University Library of Slovenia 
In many other cases, new functions are attached to 'classical' services, in which digital activities are shared most of the time with IT and Preservation departments, often in conjunction with Acquisitions, Periodicals, Special collections departments or services, sometimes with Reference, Public services.

To work well, a collaborative approach between all the services is required. Some services may be outsourced.

Which units deal with digital issues?

"Almost any activity of the library has to handle digital issues." (Lausanne, Switzerland).

"Not one but several units deal with digital issues depending on the type of issue at hand." (Cork, Ireland).

"All the services. Online and onsite services are organizationally integrated." (Utrecht, NL).

Some examples of combinations:

\begin{tabular}{|c|c|c|c|}
\hline $\begin{array}{l}\text { IT and } \\
\text { Preservation } \\
\text { (NL-Norway) }\end{array}$ & $\begin{array}{l}\text { Periodicals } \\
\text { Auto mation } \\
\text { Reference } \\
\text { (Bil kent Turkey) }\end{array}$ & $\begin{array}{l}\text { National Lib. Div. } \\
\text { University Lib. Div. } \\
\text { Computing \& Processing } \\
\text { Digitization \& web } \\
\text { (Aarhus Denmark) }\end{array}$ & $\begin{array}{l}\text { Special Coll. } \\
\text { Acq. } \\
\text { Ca aloguing } \\
\text { IT Dep. } \\
\text { ILuzern Switzl }\end{array}$ \\
\hline $\begin{array}{l}\text { IT Preservation } \\
\text { Acq - Lib - } \\
\text { Management } \\
\text { (Bern Switz) }\end{array}$ & $\begin{array}{l}\text { Periodicals } \\
\text { Public Services } \\
\text { IT Service } \\
\text { [Sorbonne France) }\end{array}$ & $\begin{array}{l}\text { Conservation } \\
\text { Computer Dep. } \\
\text { Special Coll. Dep. } \\
\text { ('warsaw Univ. Lib.) }\end{array}$ & $\begin{array}{l}\text { Special Coll. } \\
\text { Acq. } \\
\text { Preservation } \\
\text { (St Petersburg) }\end{array}$ \\
\hline
\end{tabular}

\section{TRENDS IN ACQUISITIONS AND COLLECTION DEVELOPMENT}

The important and increasing role of e-resources stands out. Some libraries mention specific departments dealing with e-resources. On the contrary, other libraries say e-resources have no special place in the structure. All libraries in Nordic countries, and many in other countries, prefer e-resources rather than printed copies if possible. The situation is more mixed in Southern and Eastern Europe. Some libraries mention limits in the range of e-resources: by subject areas or by type of resource, mostly because of their high price.

Open access (mostly in university libraries):

All libraries try to offer free access to e-resources, as far as is legal; e-publishing and electronic archiving is starting to be developed and is in place in some libraries in Nordic countries and in the Netherlands (see the example of Utrecht University Library below). Many libraries are planning this service for the near future (university libraries, national libraries of France and Spain); some university libraries will deal only with theses in this way. 


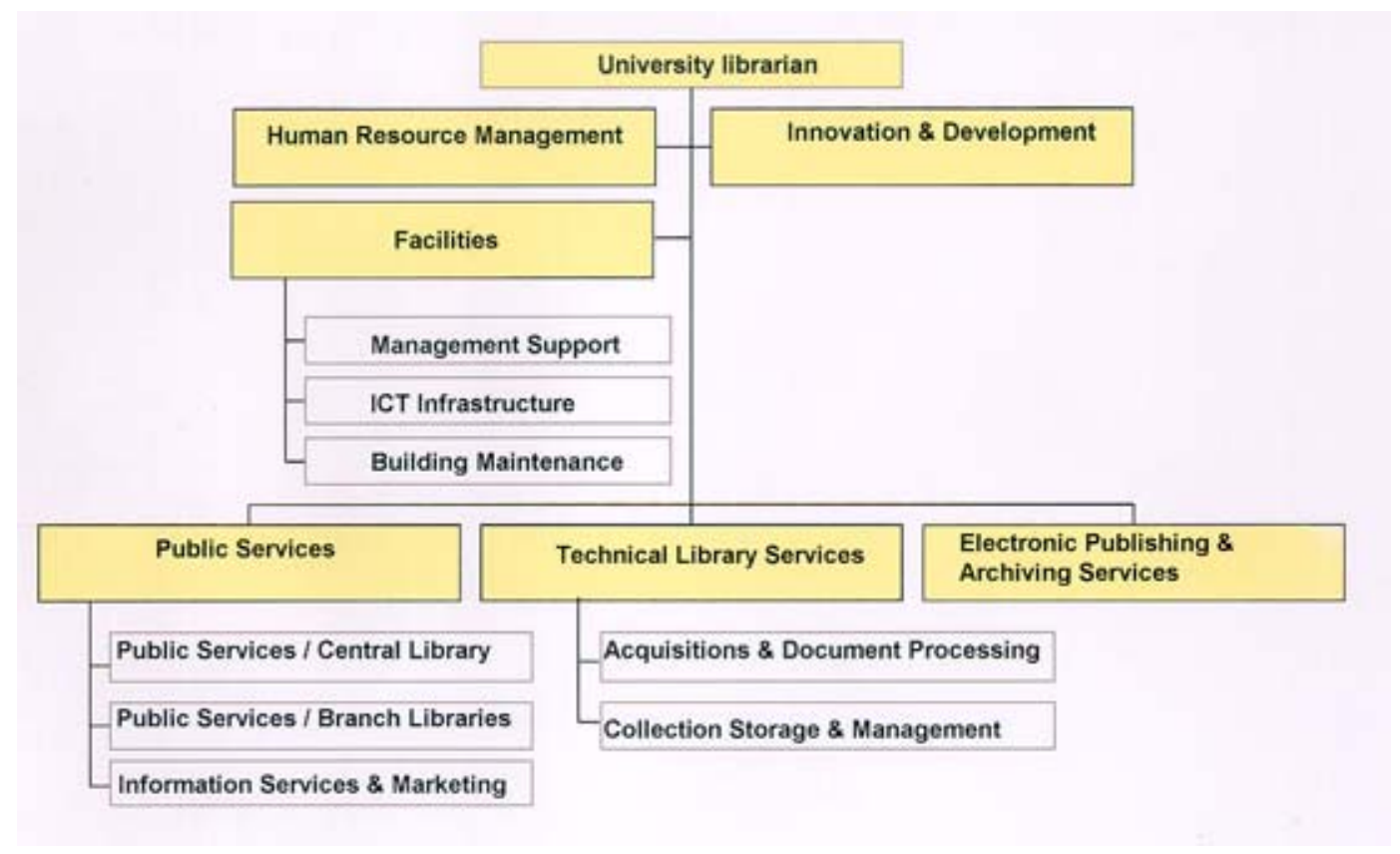

Organization chart Utrecht University Library

Consortial arrangements: all university libraries have established consortia, usually at a national or a regional level. National consortia can be established only for university and academic libraries, as in France where the different status of the libraries is clear. They can also include different sorts of libraries. In Germany and Switzerland some libraries (in the consortium) are State and University libraries. The public libraries belong to the consortium in Finland, and in Iceland "they have mainly general national licenses that provide access for all citizens that have access to the Internet." The national consortia include national libraries in Netherlands, Switzerland and Kosovo. The other national libraries (Belgium, France, Spain, Albania, Turkey) are not included.

\section{THE EVOLUTION OF LEGAL DEPOSIT}

Nearly all national libraries have legal deposit, generally of all material. In Sweden there is no legal deposit of electronic material. Similarly, only print material is deposited in the National Libraries of Albania and Turkey. The $\mathrm{BnF}$ has introduced web legal deposit, which is coordinated by the Digital Library Department. The National Library of Spain will shortly define the place of e-deposit. The National Library of Lithuania is planning to create long-term archiving of e-resources.

The place of e-resources in legal deposit is growing, with differing situations according to countries.

Digital legal deposit takes place in different ways in different organizations:

- A general legal deposit section: in the National Library of Iceland, all legal deposits, independent of type, even web harvesting, are a part of the legal deposit section.

- Cross functional activity between different sections: in the State and University Library of Aarhus (DK) the digital legal deposit is organized in a matrix - harvesting in one section, a bit of preservation in another, and selection and content control in a third.

- Planned or implemented web legal deposit services: in Switzerland and Germany regional legal deposit arrangements have been extended to e-resources. 


\section{HUMAN RESOURCES}

In a different area, one of the questions of the survey dealt with human resources. The organization of responsibility for human resources (HR) reflects library size: the director is directly responsible when staff-numbers are under 50 full time equivalent or helped by an administration officer or deputy director ( $<50-200 \mathrm{fte})$. There is a special head of administration and personnel when the number of staff is between $<50$ and $200 \mathrm{fte}$. A separate HR department exists in the largest libraries (more than $200 \mathrm{fte}$ ).

The type of library is also significant: national libraries tend to have a HR manager; in University libraries HR can be managed in cooperation with university HR management. The major trends are a professional centralized responsibility for all aspects of HR, and delegation of some well defined aspects of HR responsibility to department leaders. In some rare cases you find consultant involvement or outsourcing of HR management.

\section{INFORMATION LITERACY \& RESEARCH}

The responses to the question of teaching information literacy reveal geographical differences:

In Nordic countries and the Netherlands, all libraries teach information literacy, mainly through information specialists and reference librarians. The libraries have a group responsible for IL teaching, except at the university library of Utrecht, which says that it is integral part of public services. The situation is the same, to a lesser degree, in Swiss and German libraries.

It is more mixed in France and Belgium, with some librarians teaching IL, or with services for specific users (BnF: "service de l'action pédagogique" for teachers). This function seems to be less developed in other countries. The emphasis is on IT services (online services and e-resources). Differences in the integration of information literacy in the universities' curricula are often due to administrative and financial difficulties.

What support do members of the staff give to research in library and information sciences? The biggest university libraries and national libraries support library relevant research, but research is also often due to individual initiatives.

\section{DIFFERENCES BETWEEN NATIONAL AND UNIVERSITY LIBRARIES}

A significant number of respondents are both national and university libraries. The answers to the survey highlight differences between national libraries and university libraries, which have been especially analyzed by the French school of librarianship (ENSSIB). Due to their national obligations, national libraries place emphasis on the national collections and heritage material. Legal deposit is very important and has consequences for storage, preservation, web legal deposit for national memory and a high percentage of original cataloguing. They have often a larger size and therefore a more developed hierarchy, specific HR entity, and diversification of services (e.g. library strategy and planning, legal service).

The university libraries often have strong links with their parent institution, e.g. IT, web activities, HR, legal and accounting support. The libraries function in diverse networks with branch libraries and consortial acquisition arrangements; with e-resources there is a development of open access, of e-publishing and archiving (theses); the role of learning and research, of information literacy, is more recognized. University libraries are close neighbours to the bulk of their users.

Three examples have been chosen to compare the organization charts before and after a reorganization: Tilburg University Library (NL), the new organization (spring 2006) is the consequence of the integration of the library, IT services and the Media Center. This change has had an effect on a substantial part of the organization: for the support of teaching, learning and research; for IT maintenance and development; for project management; for help desk procedures. It has gone beyond the top level of management. 


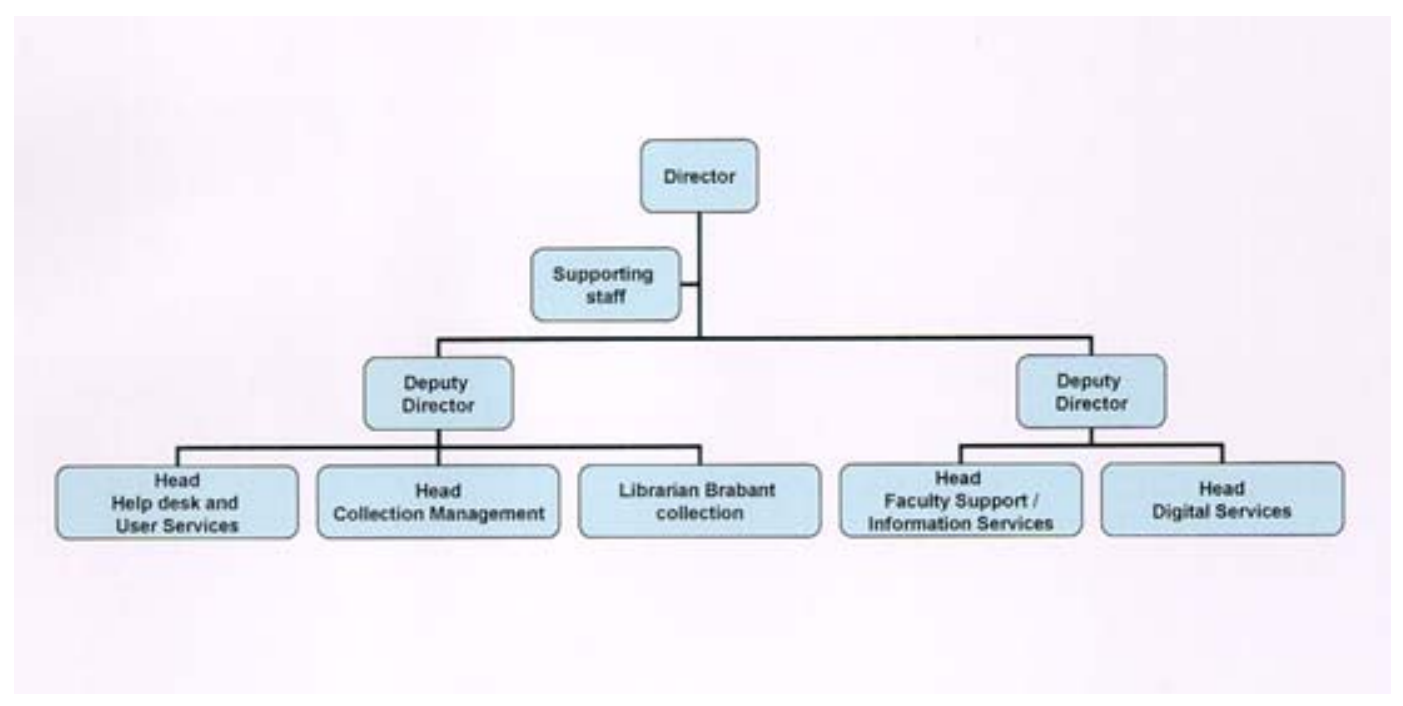

Organization chart Tilburg University Library (before)

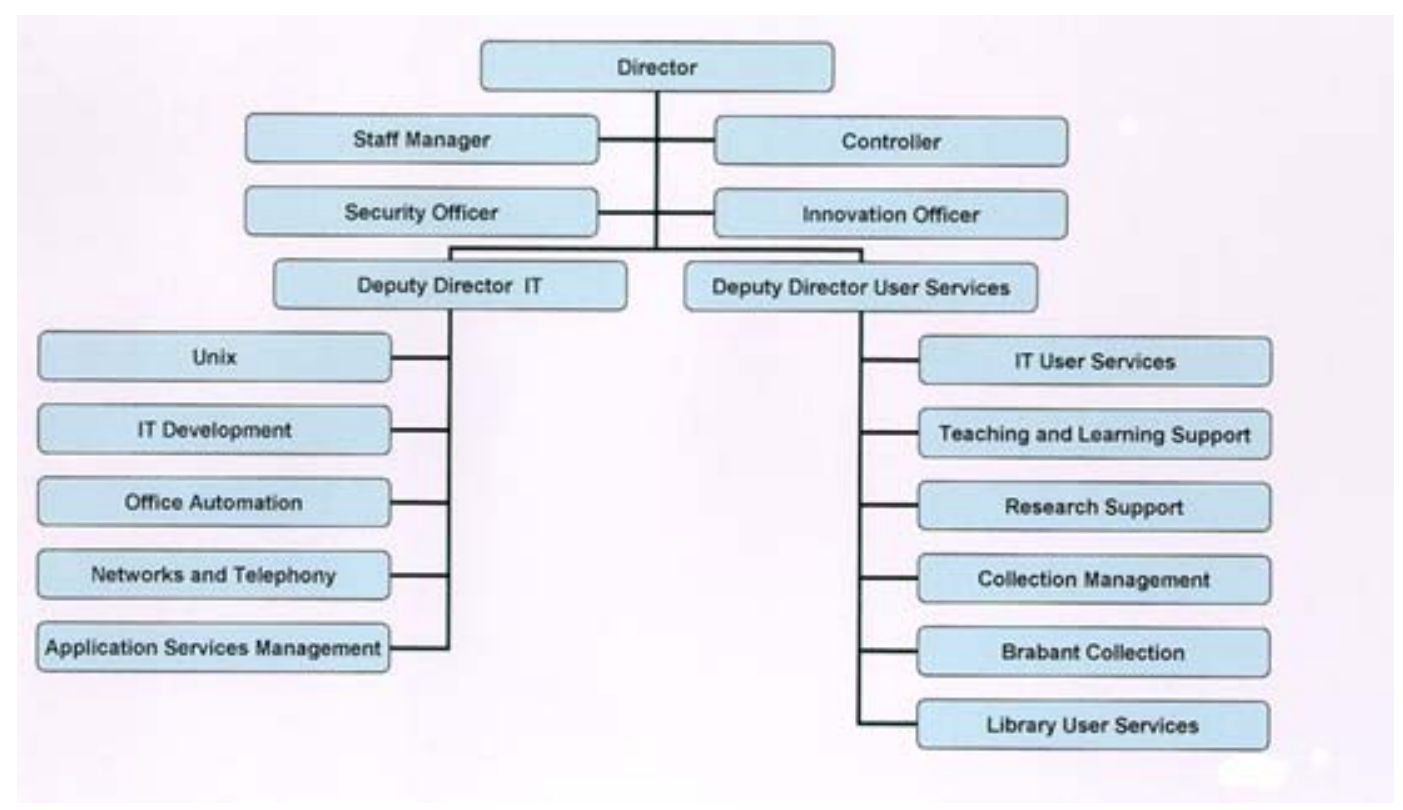

Organisation chart Library and IT Services Tilburg University Library (Spring 2006)

The Royal Library (DK) has seen the merging of the National Library of Denmark with Copenhagen University Library. The Royal Library assumed the role of university library to the University of Copenhagen in 1927 for the following faculties: Theology, Humanities and Law; the latter was later expanded to Social sciences. In 1990, the RL merged with a smaller university library, functioning in parallel between 1927 and 1989, and in 2005 with the National Library of Science and Medicine that - despite its name (since 1990) - was the Copenhagen University Library for the Faculties of Science and Medicine. Both mergers have resulted in a complete reorganization of the whole library, but reorganizations have also been carried out at other times over the years. 
The Royal Library

Organisation 2005

\begin{tabular}{|c|c|c|}
\hline & $\begin{array}{c}\text { Director } \\
\text { Erhad Kolding Niclscn }\end{array}$ & \\
\hline $\begin{array}{c}\text { Division A } \\
\text { Special Collections } \\
\text { and Reader Services } \\
\text { Steen Bille Larsen } \\
\end{array}$ & 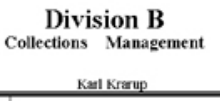 & $\begin{array}{c}\text { Division C } \\
\text { Research and } \\
\text { Corporate Services } \\
\text { Bocill Hentiksen } \\
\end{array}$ \\
\hline 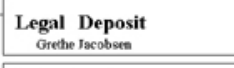 & $\begin{array}{l}\text { Documentation } \\
\text { and Digitisation } \\
\text { Birgit Hemriksen }\end{array}$ & \begin{tabular}{|l}
$\begin{array}{c}\text { Research } \\
\text { Jolin T. Lauridsen }\end{array}$ \\
\end{tabular} \\
\hline $\begin{array}{c}\text { User Services } \\
\text { Bodal Koch } \\
\end{array}$ & Main Collections & Administration \\
\hline $\begin{array}{l}\text { Special Collections } \\
\text { Manuscripts and rare } \\
\text { Books }\end{array}$ & Chariote Rohde & Bodil Henriksese \\
\hline $\begin{array}{l}\text { Jvan Bosenup, and Photo - } \\
\text { Maps, Prints and } \\
\text { graphs } \\
\text { Ingaid Fischer Jonge }\end{array}$ & $\begin{array}{l}\text { Acquisitions } \\
\text { Inger H oy Nieisen }\end{array}$ & $\begin{array}{l}\text { Technical Services } \\
\text { Logistics } \\
\text { Leo Poutsen }\end{array}$ \\
\hline $\begin{array}{l}\text { Music and Theatre } \\
\text { Nieks Knbbo } \\
\text { Orientalia and Judaica } \\
\text { Stig T. Rasnumsen }\end{array}$ & $\begin{array}{l}\text { Preservation } \\
\text { Marie Vest }\end{array}$ & $\begin{array}{l}\text { Building Services } \\
\text { Bjarne Riis Klausen }\end{array}$ \\
\hline $\begin{array}{l}\text { Cultural Activities } \\
\text { lngrid Fissther Jongs }\end{array}$ & $\begin{array}{l}\text { Computer } \\
\text { Anders Chistensen }\end{array}$ & Closes Frilis \\
\hline
\end{tabular}

Organization chart The Royal Library Copenhagen (2005)

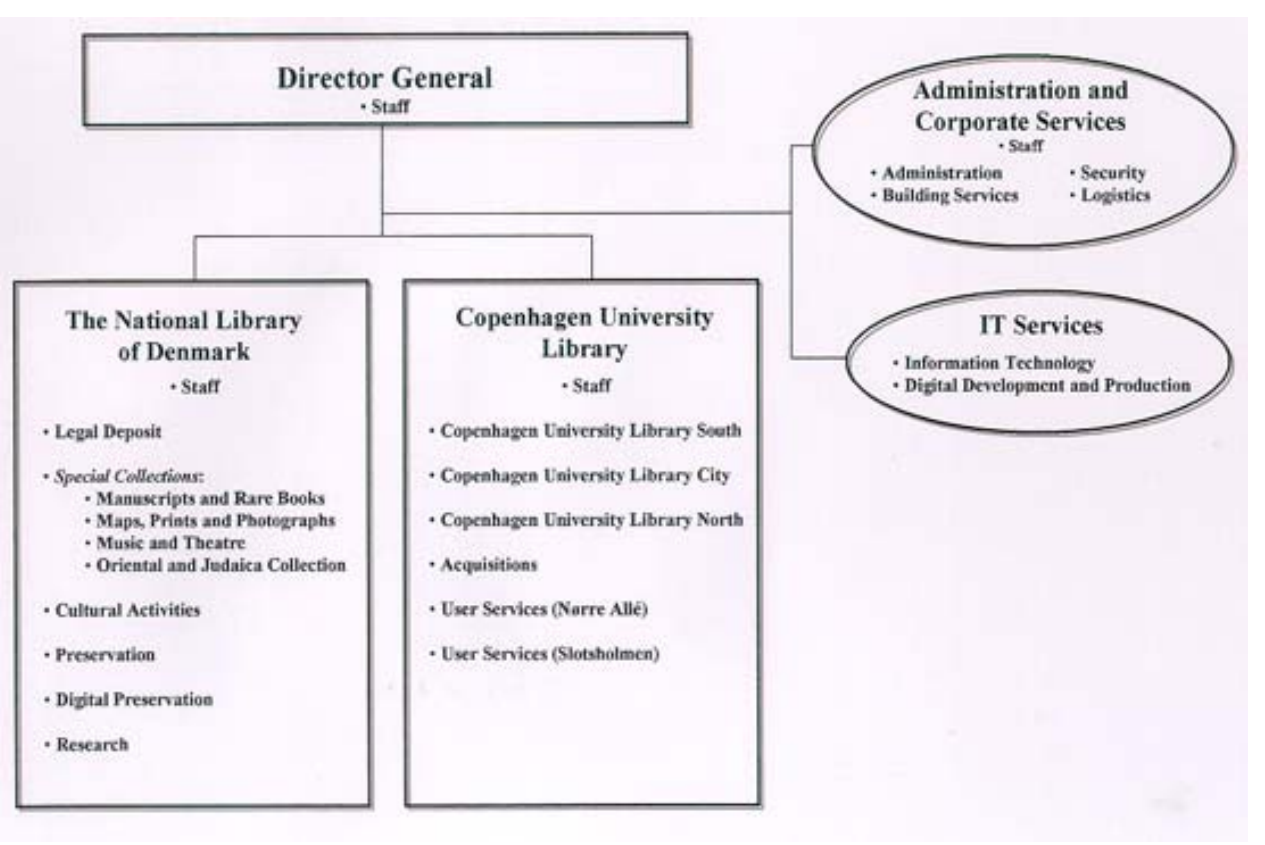

Organization chart The Royal Library Copenhagen (after the merging)

At the Ghent University Library (Belgium), a new structure was created after a radical reorganization. UL Ghent has conducted a complete restructuring of library services with the consulting support of a Swedish expert, Lars Björnshauge. The library has moved from the classical 'tree' organization towards a completely different structure. At the top is a management team, on the left wing the digital library and on the right the repository library. A big project dealing with architecture encourages the repository people and the digital group to work together. 


\section{University Library Ghent - old structure}

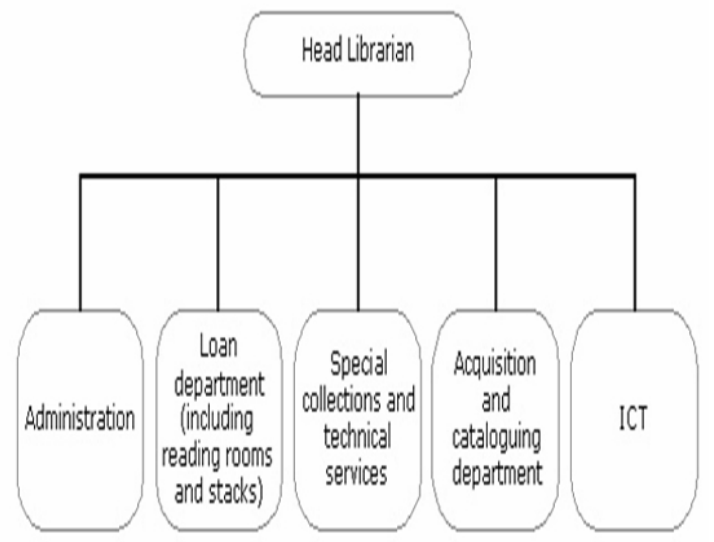

Organization chart University Library Ghent (old structure)

University Library Ghent - new structure $\left({ }^{\circ} 2004\right)$

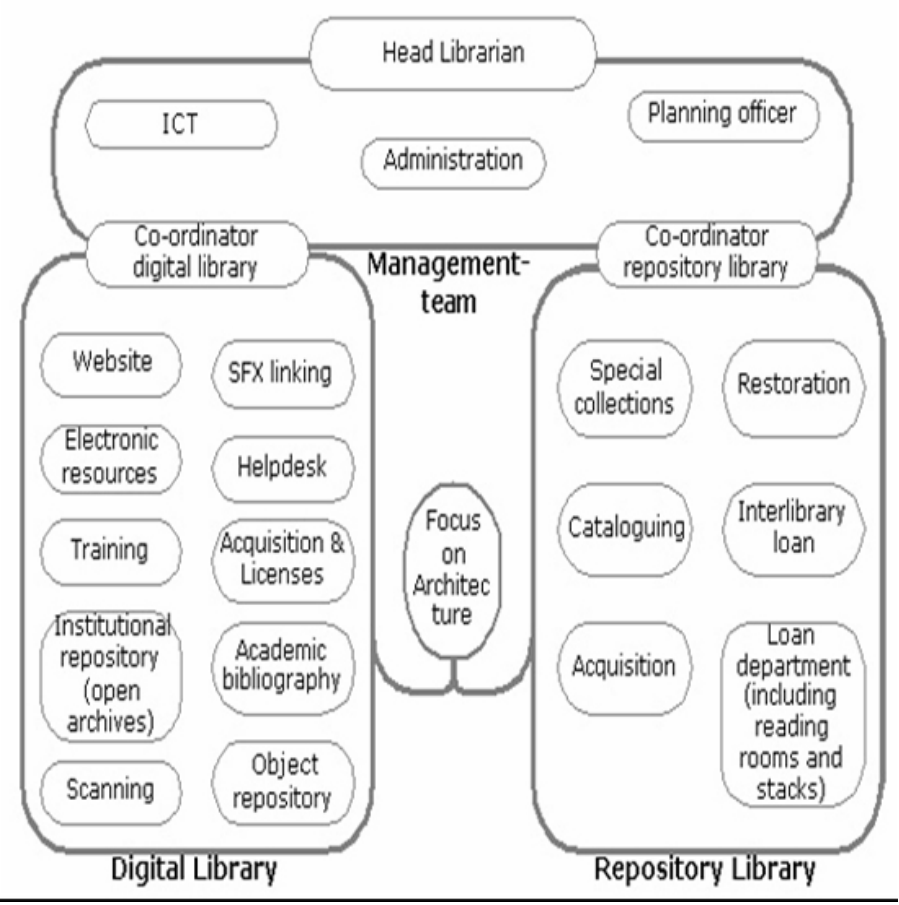

Organization chart University Library Ghent (since 2004) 
Due to the efforts of our many respondents, much important material has been collected, and exploited with the voluntary help of the LMA Division's committee and colleagues [1] in France. I am really grateful to all of them for their valuable input in this collective work. I also apologize for not mentioning in this brief article many interesting comments from the respondents and other aspects of the analysis.

\section{CONCLUSION}

First, when the libraries change their organization chart, they try to incorporate at the same time a more elaborate yet more flexible structure. The UL Ghent report mentions their goal "to create a new and modern structure that will be able to adapt itself to future changes."

Secondly, the organization charts share little in common, in terms of nomenclature, vocabulary and reporting lines. The LMA Division will try to consider the feasibility of recommendations including best practices from different examples around Europe. [2]

Finally, I should like to stress that an enormous majority of colleagues have given a positive answer to the "support declaration" at the end of the survey - "Would you be prepared to help a colleague who is about to start a reorganization project?". This is an open door for the exchange of experiences.

\section{NOTES}

1. Members of the LMA Division's committee: Bill Simpson, secretary (United Kingdom); Didar Bayir (Turkey); Suzanne Jouguelet, chair (France); Ulrich Niederer (Switzerland); Helge Salvesen (Norway) and Jolanta Stepniak (Poland).

Contribution of the Ecole nationale supérieure des Sciences de l'information et des bibliothèques (ENSSIB) : Françoise Lerouge and Bérénice Waty.

Contribution from the BnF: Françoise Bérard, Frédérique Laval and Françoise Monsallier.

2. I have found the same diversity in the organization chart examples in a recent Association of Research Libraries publication about access services. 


\section{APPENDIX 1}

LIBER Division for Library Management and Administration

Development of institutional organizational charts in some research libraries

The LIBER Library Management and Administration Division is carrying out a survey of selected libraries in order to review their organizational structures, as reflected in their organizational charts, or organograms or staff diagrams (O.C.s)

The main purpose of this investigation is twofold: to find out how significant organizational changes translate into O.C.s, and to find out in what ways research library organization has changed, particularly with regard to its impact on user services.

The questionnaire has been deliberately kept as short as possible: 20 questions, with 7 general and 13 more specific ones.

Please keep your answers reasonably short and reply in English,

\section{BEFORE 15 DECEMBER 2005}

to the person who has sent you the questionnaire,

with a copy to Suzanne Jouguelet, chair of the LMA Division : suzanne.jouguelet@,bnf.fr

Qualitative comments are welcome. Please attach a copy of your organizational chart to your reply.

The results of the survey will be analyzed by the LMA Division Committee and presented during the Uppsala Conference in July 2006. Your contribution to this survey is vital and we look forward to receiving your response. Thank you for your co-operation.

\section{A. GENERAL QUESTIONS}

1. Library name and type (- and don't forget to give your contact details at the end of the questionnaire!)
a. national
b. university
c. other

2. Size of library in terms of
a. staff
b. users
c. collections (including e-resources)

3. Governance of your library

a. Do you have a Management or Advisory Board which includes members from outside the library?

b. To whom does the Director report?

4. Organizational charts

a. Has it been updated during the last three years, or do you plan to do so?

b. If so, what are the major changes that have occurred/will occur (e.g. have you introduced new services or modified or discontinued previously existing activities)?

5. How many hierarchical levels do you have?

6. Does your library manage different operational entities: e.g. a central or main library and separate branches? Is this shown in your O.C.?

7. Do you have separate locations for storage? 
If so, how many? How far are they from your main building?

\section{B. SPECIFIC QUESTIONS}

8. Users / Public services

a. Have you recently created new services or significantly modified existing services. If so, which?

b. Is the balance or the difference between your online and on-site services reflected in your staff structure?

c. How do you persuade your readers to use online services?

9. The Digital library

a. Does your Library have a central unit dealing with digital issues?

b. If not, which individual activities (e.g. Special Collections, Acquisitions, Preservation) have digital responsibilities?

10. Web activities

a. Are they reflected in your O.C., and how ? (web site, web archiving, e-access....)

b. How many Library staff are involved:

- $\quad$ in creating content ?

- $\quad$ in maintaining your web presence?

c. (if a University Library:) How are your web activities linked to those of your parent institution?

11. Do you have specific units or individuals responsible for: (- we understand that ultimately the director is responsible for these activities, but our question is: is there someone else whose job description contains one of the following elements)

a. Development of library strategy / planning

b. Benchmarking and performance measurement

c. Fundraising and sponsorship

d. Legal matters (intellectual property rights, etc)

e. Publicity and marketing (outreach activities)

Please give the dates of creation of these units wherever possible.

12. Collection management

What is the organizational relationship between collection management and public services in your organizational structure?

13. Acquisitions and collections development

a. What is the place of e-resources in your library structure ? Do you choose e- rather than print resources when possible? Have you developed open access for e-resources?

b. Do you have consortial acquisition arrangements with other libraries ? (If so, is it on a national/regional/local basis or by type of library?)

c. If your library receives legal deposit, which are the internal library arrangements about the organizational place of a legal deposit group? (mainly about electronic resources)

d. Are your acquisitions and cataloguing staff integrated into a single unit or department, or do they work separately?

14. Cataloguing

a. How much of your cataloguing is original rather than provided by a records supplier or under a shared arrangement with other libraries?

- $\quad$ under $30 \%$

- $\quad 30 \%$ to $50 \%$

b. Have you introduced any of the following developments - and how do they show up in your O.C.?

- $\quad$ New formats and rules of description (eg. Dublin Core) 
- $\quad$ Subcontracting / outsourcing

15. Preservation

a. Where does preservation appear in your O.C. ?

b. Do you undertake electronic storage ? Does it appear in the O.C.?

16. Information systems and technology

a. Does your library run its own IT services itself (Library Management System, staff workstations network) or are they the responsibility of your parent organization?

b. Does your Library have specialist staff for these activities? How many ? Has the number been growing in the last three years?

c. Have you changed your automated library management system in the last three years or do you have plans to do so within the next year?

d. Do you plan to create institutional repositories ?

17. Human resources

a. Who is responsible for HR in the library ? For which aspects?

b. Who is in charge of staff development?

c. Do you use externally-provided as well as internal training?

18. Learning and research

a. Do you have a group responsible for teaching information literacy? If you are a university library, how is information literacy integrated in the university's curricula?

b. Do you encourage or support (and, if so, who in your structure does this) research in library and information sciences by your collaborators?

19. Communications

a. How is communication with staff (in house newsletter etc...) reflected in the O.C.?

b. Do you have a public relations department/person? How/where does this department/person fit into your organizational structure?

20. Administration/finance, and financial control

a. Where do they appear in your O.C.?

b. Do you share functions with other parts of the organization (e.g. the central University)?

C. " SUPPORT DECLARATION"

Would you be prepared to help a colleague who is about to start a reorganization project?

YES NO

- Name and title of the respondent

- Institution

- email address

- Date 


\section{APPENDIX 2}

LIBER : Questionnaire Organigrammes

Number of reactions received 17 July 2006

\begin{tabular}{|c|c|c|}
\hline Albania & (DB) & 1 \\
\hline Belarus & (JS) & 1 \\
\hline Belgium & (SJ) & 2 \\
\hline Bulgaria & (JS) & 1 \\
\hline Croatia & (BS) & 3 \\
\hline Cyprus & (DB) & 1 \\
\hline Czech Rep & (JS) & 4 \\
\hline Denmark & (HS) & 4 \\
\hline Estonia & (JS) & 1 \\
\hline Finland & (HS) & 2 \\
\hline France & (SJ) & 7 \\
\hline Germany & $(\mathrm{UN})$ & 2 \\
\hline Greece & (DB) & 1 \\
\hline Hungary & (JS) & 2 \\
\hline Iceland & (HS) & 1 \\
\hline Ireland & (BS) & 1 \\
\hline Italy & $(\mathrm{UN})$ & 2 \\
\hline Kosovo & (DB) & 1 \\
\hline Latvia & (JS) & 1 \\
\hline Lithuania & (JS) & 3 \\
\hline Malta & (BS) & 2 \\
\hline Netherlands & (SJ) & 4 \\
\hline Norway & (HS) & 3 \\
\hline Poland & (JS) & 3 \\
\hline Russia & (BS) & 2 \\
\hline
\end{tabular}




\begin{tabular}{|l|l|l|}
\hline Serbia & (BS) & $\mathbf{1}$ \\
\hline Slovakia & (JS) & $\mathbf{1}$ \\
\hline Slovenia & (JS) & $\mathbf{2}$ \\
\hline Spain & (SJ) & $\mathbf{1}$ \\
\hline Sweden & (HS) & $\mathbf{3}$ \\
\hline Switzerland & (UN) & $\mathbf{6}$ \\
\hline Turkey & (DB) & $\mathbf{3}$ \\
\hline United Kingdom & (BS) & $\mathbf{6}$ \\
\hline & & $\mathbf{7 8}$ \\
\hline
\end{tabular}

NB: No reaction from Austria, Luxembourg, Portugal, Rumania, and Ukrain. 